\title{
Telerehabilitacja - nowa forma pomocy pacjentom korzystającym z systemu implantu ślimakowego w ramach programu opieki pooperacyjnej
}

\section{Telerehabilitation - a new form of help to patients who are using the cochlear implant under the postoperative care}

\author{
Agnieszka Pankowska ${ }^{1,2}$, Joanna Solnica ${ }^{1,2}$, Henryk Skarżyński ${ }^{1,2}$ \\ ${ }^{1}$ Instytut Fizjologii i Patologii Słuchu, ul. Zgrupowania AK „Kampinos” 1, 01-943 Warszawa
${ }^{2}$ Światowe Centrum Słuchu, ul. Mokra 17, Kajetany, 05-830 Nadarzyn
}

Adres autora: Agnieszka Pankowska, Światowe Centrum Słuchu, ul. Mokra 17, Kajetany, 05-830 Nadarzyn; tel. 22 3560335, e-mail: a.pankowska@ifps.org.pl

\begin{abstract}
Streszczenie
Szybki postęp technologii i zmieniający się stan wiedzy o możliwościach, jakie uzyskujemy po zastosowaniu leczenia różnych ubytków słuchu, wieloletnie doświadczenie w organizacji i prowadzeniu opieki nad naszymi pacjentami, redukcja kosztów oraz oszczędność czasu niezbędnego na podróż do odległego ośrodka specjalistycznego stały się istotnym impulsem do stworzenia nowej formy pomocy pacjentom korzystającym z systemu implantu ślimakowego. Obecnie w celu realizacji opieki pooperacyjnej mogą oni zostać objęci terapią słuchu i mowy ramach programu telerehabilitacji. Program ten jest skierowany do szerokiej rzeszy pacjentów, zarówno dzieci jak i dorosłych, ale również do specjalistów z ośrodków na terenie całego kraju, a za ich pośrednictwem do studentów, nauczycieli i wychowawców. Jak wynika z naszych dotychczasowych doświadczeń staje się on coraz chętniej przyjmowany przez pacjentów i nie ustępuje pomocy realizowanej w bezpośrednich kontaktach ze specjalistami.
\end{abstract}

Słowa kluczowe: telerehabilitacja • telemedycyna • implant ślimakowy

Abstract

Rapid technological progress, developing knowledge about the possibilities of treatment of different hearing disorders, many years of experience in organizing and providing care for our patients, pursuit of the reduction of costs and time spent on travel to distant specialist centers, were the factors that have combined to inspire to create the new form of help for implanted patients. Currently the patients are also provided postoperative hearing and speech therapy within a telerehabilitation program. It is addressed to a broad group of patients, children and adults, but also specialists from centers located across Poland, as well as students, teachers and educators cooperating with the centers. Our experience shows that this method of therapy becomes more popular among patients and it is fulfilling the same standards as direct contact with specialists

Key words: telerehabilitation • telemedicine $\bullet$ cochlear implant

Zgodnie z definicją terminem „telerehabilitacja” określane jest postępowanie służące dostarczeniu odbiorcy usług rehabilitacyjnych z wykorzystaniem sieci połączeń telekomunikacyjnych i internetu. Tą formą pomocy obejmowane są wciąż nowe grupy pacjentów. W powszechnym rozumieniu telerehabilitacja kojarzona jest $\mathrm{z}$ bezpośrednim łączeniem się z pomocą tzw. komunikatorów (Skype, itp.) z pacjentem i prowadzeniem ćwiczeń „na odległość”. Podejściu temu trudno nie przyznać racji, jednak ogranicza ono wachlarz możliwości, jakie niesie ta forma pomocy.

W Instytucie Fizjologii i Patologii Słuchu początki telekonsultacji miały miejsce w 2005 roku. Ideę tę systematycznie rozwijano w Międzynarodowym Centrum Słuchu i Mowy. Obecnie dysponujemy w Światowym Centrum Słuchu profesjonalnym studiem, z którego można prowadzić, bądź monitorować zajęcia w kilku miejscach równolegle. $\mathrm{W}$ reprezentowanym przez specjalistów z IFPS rozumieniu zadań i roli telerehabilitacji dominuje przekonanie, że obejmuje ona wykorzystanie wiedzy i doświadczenia specjalistów oraz najnowszych osiągnięć technicznych w celu stałego towarzyszenia pacjentowi w realizacji zadań służących budowaniu lub usprawnianiu umiejętności słuchowych, językowych i komunikacyjnych. Telerehabilitacja to również współdziałanie z rodziną, najbliższym otoczeniem, nauczycielami, 


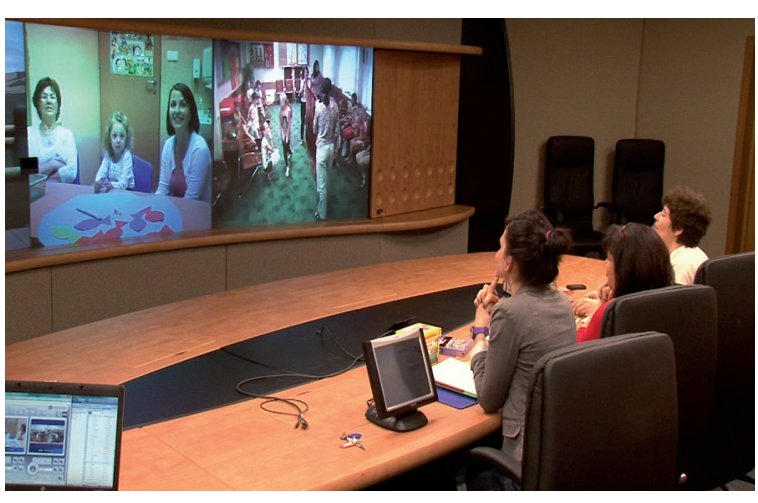

a więc osobami, z którymi w codziennych sytuacjach funkcjonuje nasz pacjent.

Celem pracy jest przedstawienie grupy odbiorców, która może korzystać z rehabilitacji słuchu i mowy organizowanej w systemie „tele”, rodzaju i charakteru oferowanych konsultacji oraz porad, placówek uczestniczących w programie pooperacyjnej opieki nad pacjentami implantowanymi oraz naszych spostrzeżeń z dotychczas realizowanych konsultacji.

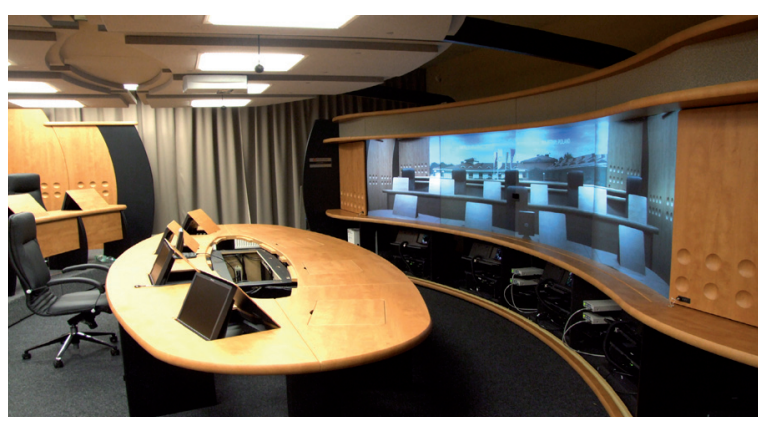

\section{Odbiorcy programu telerehabilitacji}

Metoda telerehabilitacji jest skierowana zarówno do dzieci, jak i osób dorosłych, ze stwierdzoną częściową głuchotą, które po badaniach diagnostycznych zostały zakwalifikowane do leczenia $\mathrm{z}$ wykorzystaniem systemu implantu ślimakowego. Jak wynika z naszych doświadczeń wśród dzieci większość stanowią obecnie pacjenci, u których stwierdzono:

- ograniczone możliwości odbioru, różnicowania oraz rozpoznawania dźwięków przedmiotowych i mowy; odbiór komunikatów słownych ze wsparciem kanału wzrokowego,

- opanowanie zasobu leksykalnego na poziomie wieku rozwojowego przy ograniczonej świadomości fonologicznej płaszczyzny języka oraz problemy z zastosowaniem reguł gramatycznych organizujących wypowiedź,

- wyraźne zaburzenia w zakresie wymowy głosek, zwłaszcza z obszaru wysokich częstotliwości oraz zaburzenia prozodii mowy przy zachowanej lub rozwijanej komunikacji werbalnej.

W sytuacji osób dorosłych największym problemem są ograniczenia w odbiorze i rozumieniu mowy, ale również, choć w zdecydowanie mniejszej grupie, wadliwe realizacje głosek, utrudniające zrozumienie tworzonych przez nich wypowiedzi. W obu wspomnianych grupach odnotowujemy także trudności w innych sferach życia. U dzieci są to trudności

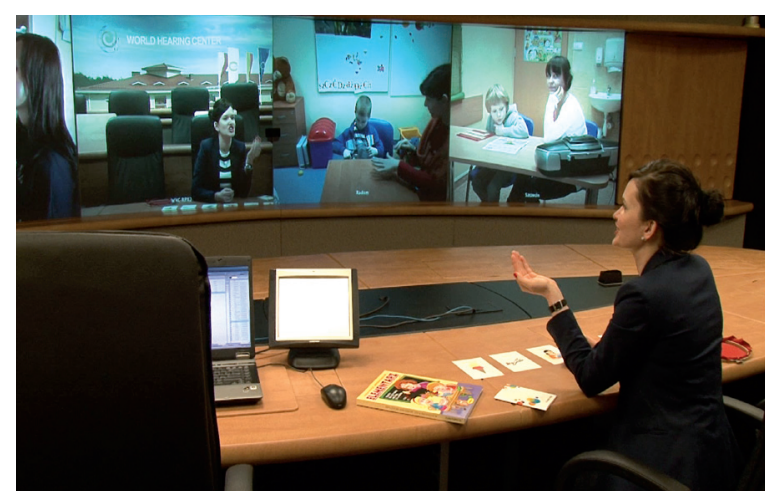

szkolne, ubogie kontakty $\mathrm{z}$ rówieśnikami, niska odporność na sytuacje stresowe. $U$ dorosłych natomiast ograniczony udział w życiu społecznym, trudności w korzystaniu z mediów, poczucie odmienności, śmieszności, izolacji, a w wielu przypadkach pogorszenie ogólnej kondycji psychicznej. Wskazane powyżej nieprawidłowości kwalifikują pacjentów do działań o charakterze rehabilitacyjnym lub terapeutycznym i wyznaczają udział różnych specjalistów.

\section{Rodzaje konsultacji w ramach programu telerehabilitacji}

$\mathrm{W}$ ramach opieki organizowanej w systemie telerehabilitacji dla pacjentów przygotowane są różne rodzaje konsultacji:

Konsultacje indywidualne prowadzone lub monitorowane ze studia na terenie Światowego Centrum Słuchu. Obejmują one zaplanowane, systematyczne zajęcia. Pacjent przebywa w jednym z ośrodków filialnych lub współpracujących ze Światowym Centrum Słuchu, blisko miejsca zamieszkania i samodzielnie lub przy współpracy oraz pomocy lokalnego specjalisty, rodzica czy opiekuna realizowane są kolejne ćwiczenia czy zadania. Omawiane lub prezentowane mogą być również ćwiczenia zaplanowane do samodzielnego wykonania w warunkach domowych.

Konsultacje interwencyjne organizowane w związku z problemem zgłaszanym przez rodzica/opiekuna, specjalistę ze Światowego Centrum Słuchu bądź specjalistę z ośrodka lokalnego.

Konsultacje obejmujące badania i zdalne programowanie procesora mowy, które już od kilku lat stanowią stały element współpracy pacjenta z inżynierem klinicznym, jak również z logopedą w celu oceny lub obserwacji efektów leczenia i rehabilitacji słuchu pacjenta.

Konsultacje grupowe są prowadzone ze studia Światowego Centrum Słuchu bądź podczas organizowanych przez Instytut pobytów rehabilitacyjnych w ośrodku w Łebie (prezentacje prowadzone przez różnych specjalistów, monitorowanie przebiegu zajęć, obserwacja pracy pacjentów, osób towarzyszących, terapeutów), bądź na zaproszenie szkół, przedszkoli, poradni (konsultacje o charakterze szkoleniowym czy informacyjnym).

Pacjenci otrzymują informacje o możliwościach korzystania z pomocy w systemie telerehabilitacji już na etapie diagnostycznym, a w czasie pobytu związanego z pierwszym 


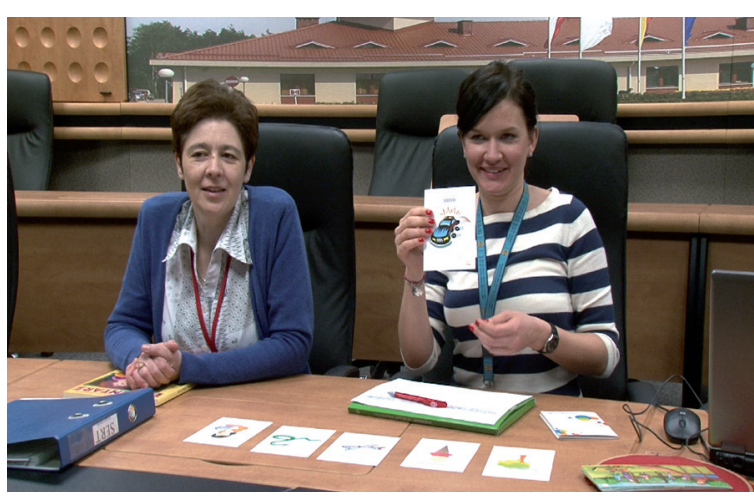

podłączeniem procesora mowy - listę ośrodków współpracujących, położonych najbliżej miejsca zamieszkania. Wówczas deklarują czy rehabilitacja słuchu i/lub mowy będzie prowadzona w systemie przyjazdów na zajęcia do Światowego Centrum Słuchu, czy w ramach udziału w programie telekonsultacji.

\section{Placówki uczestniczące w realizacji programu telerehabilitacji}

1. Ośrodek nadrzędny - Światowe Centrum Słuchu. Tu prowadzone są prace związane z planowaniem działań, koordynacją ich przebiegu oraz praktyczną realizacją poszczególnych jego elementów.

2. Ośrodki współpracujące - poradnie, ośrodki terapii, które dotychczas współpracowały z placówka nadrzędną oraz nowe jednostki, które po przebytych szkoleniach, włączone zostały do grona realizatorów programu, znajdujące się w różnych województwach na terenie kraju.

Ośrodek nadrzędny - tutaj pacjent otrzymuje wszelkie informacje na temat metod i form pracy, jakie składają się na wypełnienie zadań wpisanych w terapię słuchu i mowy. Stosownie do indywidualnych możliwości (kompetencje słuchowe i komunikacyjne do czasu leczenia z wykorzystaniem systemu implantu ślimakowego, edukacja, zatrudnienie, dostępne środki, odległość do ośrodka implantującego - Światowego Centrum Słuchu, itp.), ale również potrzeb, dokonany zostaje wybór modelu rehabilitacji. Pacjent może w porozumieniu ze specjalistą podjąć decyzję o wypełnianiu programu opieki pooperacyjnej w ośrodku współpracującym położonym najbliżej jego miejsca zamieszkania. Ośrodek nadrzędny i ośrodek współpracujący rozpoczynają wówczas systematyczną współpracę z wykorzystaniem systemu połączeń telekonferencyjnych, internetu, poczty elektronicznej, itp., aby zapewnić pełną opiekę i monitorowanie przebiegu terapii.

Ośrodek współpracujący - jest wykonawcą działań wpisanych w ogólny program terapii oraz koordynatorem programu opieki lokalnej. Do jego zadań należą:

- nawiązanie kontaktu z pacjentem (na podstawie informacji otrzymanych z ośrodka nadrzędnego lub bezpośrednio po zgłoszeniu się pacjenta do placówki),

- stworzenie indywidualnego planu rehabilitacji pacjenta $\mathrm{z}$ uwzględnieniem potrzeb w zakresie terapii słuchu i mowy, ale również - po stosownym rozpoznaniu

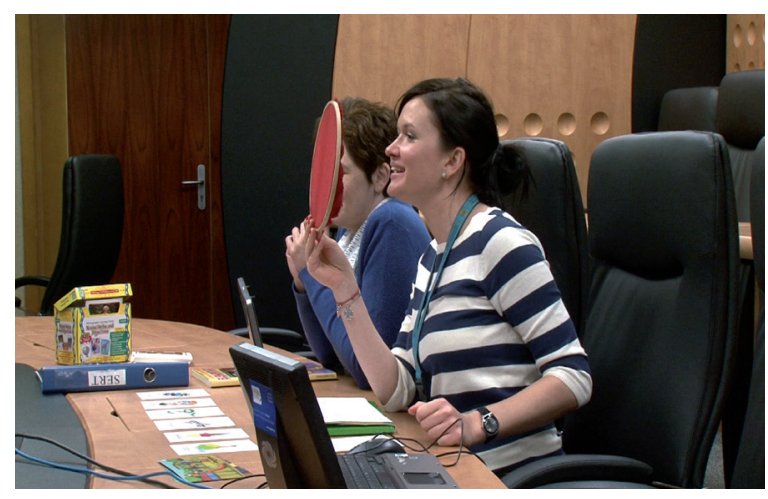

sytuacji - w odniesieniu do aktualnych potrzeb edukacyjnych bądź zawodowych (określenie zakresu, tematyki, częstotliwości spotkań, udziału innych specjalistów, itp.),

- organizacja i prowadzenie zajęć rehabilitacyjnych,

- systematyczny kontakt z ośrodkiem nadrzędnym w celu przekazywania aktualnych informacji o potrzebach rehabilitacyjnych oraz o efektach prowadzonych działań.

Częstotliwość spotkań realizowanych poprzez system telełączności jest dopasowywana do indywidualnych potrzeb pacjentów oraz do możliwości udziału wskazanych specjalistów.

Jak wynika z naszych doświadczeń konsultacje realizowane w systemie „tele" stanowią istotny element w organizacji programów opieki pooperacyjnej dla omawianej grupy pacjentów. Dostęp do najnowszych osiągnięć technicznych pokonuje barierę odległości, oszczędza środki i czas. W swoim założeniu realizowane są najważniejsze cele tej formy opieki:

- wszechstronna, wielospecjalistyczna pomoc pacjentom po przebytej operacji wszczepienia implantu ślimakowego w różnym wieku w ramach ujednoliconej i kompleksowej opieki uwzględniającej specyficzne potrzeby i możliwości tej grupy osób,

- koordynacja etapów procesu rehabilitacji służących budowaniu lub przywróceniu pacjentom możliwości słuchowego odbioru, porównywania i rozpoznawania bodźców akustycznych, a dzięki systematycznemu treningowi - stworzenie lub odtworzenie możliwości podejmowania komunikacji słownej, której zaburzenia wynikają z ubytku słuchu,

- wykorzystanie wiedzy, doświadczenia i osiągnięć multidyscyplinarnego zespołu specjalistów w celu powoływania i realizacji skutecznych programów terapii słuchu i mowy, oddziaływania na otoczenie pacjenta, pomoc w edukacji i społecznej adaptacji,

- rozpowszechnianie wiedzy na temat stosowania systemów implantów ślimakowych wśród pacjentów z częściową głuchotą.

Podsumowując, jak wynika z naszych obserwacji, ale co najważniejsze także z obserwacji pacjentów, dzięki jakości przekazu, jaką możemy zaoferować, program pooperacyjnej opieki realizowany $w$ formule telerehabilitacji nie ustępuje pomocy realizowanej w bezpośrednich kontaktach pacjenta ze specjalistami. 


\section{Piśmiennictwo:}

1. Pankowska A., Zgoda M., Skarżyński H. i wsp.: Home Rehabilitation Clinic as a Form of Support for Parents of Implanted Children. Cochlear Implants International Proceedings of the 9 \{th Europen Symposium on Paediatric Cochlear Implantation, 2010; 11(Suppl.1): 360-63

2. Wąsowski A., Skarżyński P., Lorens A. i wsp.: Remote Fitting of Cochlear Implant System. Cochlear Implants International Proceedings of the 9\{th Europen Symposium on Paediatric Cochlear Implantation, 2010; 11(Suppl.1): 489-92

3. Skarżyński H., Lorens A., Piotrowska A.: A new method of partial deafness treatment. Med Sci Monit, 2003; 9(4): CS20-24
4. Solnica J., Pankowska A., Wasowski A. i wsp.: Home Rehabilitation Clinic (HRC) - the proposal of solution of organizing rehabilitation close to patient's home. 10 \{th European Symposium on Pediatric Cochlear Implantation, 2011; 261-64

5. Solnica J., Kobosko J., Pankowska A. i wsp.: Efektywność treningu słuchowego osób z częściową głuchotą po wszczepieniu implantu ślimakowego w ocenie pacjentów i logopedów. Nowa Audiofonologia, 2012; 1(1): 31-37

6. Pankowska A., Solnica J., Skarżyński H.: Wykorzystanie zmodyfikowanego profilu umiejętności słuchowych w obserwacji efektów rehabilitacji słuchu dorosłych pacjentów z częściową głuchotą korzystających z systemu implantu ślimakowego doniesienia wstępne. Nowa Audiofonologia, 2012; 1(1): 38-45 